Berninger, M., Fiesenig, B. and Schiereck, D. (2021), "The performance of corporate bond issuers in times of financial crisis: empirical evidence from Latin America", Journal of Risk Finance, Vol. 22 No. 1, pp. 78-92.

'This author accepted manuscript is deposited under a Creative Commons Attribution Non-commercial 4.0 International (CC BY-NC) license. This means that anyone may distribute, adapt, and build upon the work for non-commercial purposes, subject to full attribution. If you wish to use this manuscript for commercial purposes, please contactpermissions@emerald.com'

\title{
The Performance of Corporate Bond Issuers in Times of Financial Crisis' - Empirical Evidence from Latin America
}

\author{
Marc Berninger $^{\mathrm{a},}$,, Bruno Fiesenig ${ }^{\mathrm{a}}$, Dirk Schiereck ${ }^{\mathrm{a}}$ \\ a) Department of Business Administration, Economics and Law, \\ Technical University of Darmstadt, Hochschulstrasse 1, 64289 Darmstadt, Germany
}

\begin{abstract}
Purpose

The fundamental theory of Modigliani \& Miller (1958) states that firm's financing decisions are independent from the firm's value. Nevertheless several empirical studies as well as theoretical approaches from the past decade impugn this relation for real markets with their immanent inefficiencies. However these questions are rather than academic in nature: Especially the influence of macroeconomic conditions on the market perception of debt issues are from high economic importance, since the need for new liquidity usually becomes even more urgent when the economic conditions worsen.
\end{abstract}

\section{Design/methodology/approach}

This paper analyzes the reaction of shareholders to the issue of debt by Latin American firms under special consideration of the macroeconomic sentiment. To do so, a sample of debt issued by Latin American companies between 2003 and 2010 is empirically examined through an event study. 
Berninger, M., Fiesenig, B. and Schiereck, D. (2021), "The performance of corporate bond issuers in times of financial crisis: empirical evidence from Latin America", Journal of Risk Finance, Vol. 22 No. 1, pp. 78-92.

\section{Findings}

We empirically demonstrate that specifically in Latin America, debt issuing companies show a significant underperformance during recessionary periods and an overperformance during nonrecessionary periods. These findings differ from previous results for mature capital markets. We conclude that not only the overall economic conditions matter to explain stock market reactions on bond issues but also the maturity of the corporate debt market plays an important role.

\section{Originality}

We provide first evidence that the previously described changes in the returns on specific stocks depending on the economic sentiment (Baker and Wurgler, 2006) are under certain conditions also present in the market for corporate debt.

Keywords: Emerging markets, debt issue, sentiment, event study, corporate debt, financing decisions, firm value

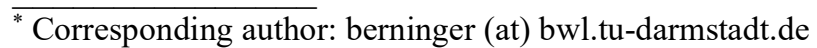


Berninger, M., Fiesenig, B. and Schiereck, D. (2021), "The performance of corporate bond issuers in times of financial crisis: empirical evidence from Latin America", Journal of Risk Finance, Vol. 22 No. 1, pp. 78-92.

\section{INTRODUCTION}

The first five months of 2020 show an overall global volume of corporate bond issues which is far above the numbers of 2018 and 2019 (Jones, 2020). These patterns indicate the high importance of debt financing in times of economic crises like the current global lockdowns during the COVID19 pandemic. Crises unmask the resilience of business models in times of extreme uncertainty and high levels of information asymmetry (van der Vegt, et al., 2015). From the shareholders' perspective of an issuing company, the announcement of a new bond issue is an important event which results in a revaluation of the company's equity. On the one side, a bond issue signals the need for liquidity, on the other side, a successful placement in the debt markets indicates trust in the future perspectives of the company. This critical weighing up is especially difficult in regions of an enduring instable macroeconomic environment like in Latin America.

More or less all economies in Latin America are heavily hit by the COVID-19 pandemic with its unprecedented economic contraction (UN, 2020) and the countries' recoveries will strongly depend on the ability to raise further financial resources via the capital markets. Given this background, we focus on the debt issues of large exchange-listed Latin American companies during the global financial crisis of 2008 to derive expected implications for today's crisis in that region. The period between 2003 and 2007 was the biggest period of economic growth since the 1970s in Latin America which was strongly affected by a trading shock in September 2008, marking the beginning of the recession in Latin America (Ocampo, 2009). However, most Latin American countries rebounded quickly due to the increased demand for natural resources from China in 2009 (Franko, 2019; Alfaro et al., 2017). A similar pattern could be expected today.

According to the Modigliani-Miller Theorem of capital irrelevance (1958), the decision to either issue debt capital or equity has no influence on an overall firm's value, financing does not matter. Nonetheless, a large body of empirical evidence shows diverging findings for decades. While an early study by Dann and Mikkelson (1984) reports significant negative share price reactions on convertible debt offerings, Eckbo (1986) presents, along with the same results for convertible debt, non-positive returns following straight debt issues. Spiess and Affleck-Graves (1999) observe a long-run underperformance of stock returns following the issue of both straight and convertible debt. However, there is also evidence of a long-run performance not different from zero for straight debt issuing companies (Dichev and Piotrosky, 1999; Jewell and Livingston, 1997). More recently, 
Berninger, M., Fiesenig, B. and Schiereck, D. (2021), "The performance of corporate bond issuers in times of financial crisis: empirical evidence from Latin America", Journal of Risk Finance, Vol. 22 No. 1, pp. 78-92.

Davydov et al. (2014), as well as Godlewski et al. (2011) also find evidence of negative cumulative average abnormal returns (CAAR) following straight bond issues for a sample of Russian firms. Especially these investigations of bond and stock markets in Russia could be a better indicator for the economic conditions in Latin America, since the effects in emerging markets such as Russia and countries of Latin America may differ from the effects in the United States or Europe. The latter represent the vast majority of the samples used in the current studies on the topic.

The overall inconsistent findings on shareholders' reactions towards debt offering indicate that additional factors might influence this stock market reaction. Madura and Akhigbe (1995) show a significant positive relation between economic growth and the stock returns following debt offerings. Davydov (2016) examines how a high level of bank debt instead of public debt can enhance firms' profitability in BRIC (Brazil, Russia, India and China) countries over the period 2003-2012. Another previously identified factor is the influence of an economic recession to the shareholders' perception of debt issues. Davydov and Vähämaa (2013) perceive that Russian firms relying on bank debt significantly outperform firms with public debt during recessionary periods, while the difference during non-economic conditions remains insignificant. Baker and Wurgler (2006) argue that investor's sentiment, which worsens during recessionary periods, changes the returns on specific types of stocks, such as high volatility and extreme-growth stocks. Consistent to this evidence, there is recent evidence of an increase in systematic risk and a decrease of risk-adjusted returns in the UK during periods of bad economic conditions, leading to increasing negative stock returns during such periods (Koutmos et al., 2018).

This paper aims to examine whether the presence of recessionary periods have the same influence in stock returns following debt issue announcements in Latin America. To examine this influence on shareholders' sentiment towards corporate debt issuing, we concentrate on the global financial crisis of 2008 to differentiate periods of good and bad economic conditions to analyze stock returns of debt issuing Latin American firms. We further conduct comparisons between mature and emerging financial markets to point out characteristic differences in times of turmoil. We therefore relay on the previous findings of Koutmos et al. (2018) who analyzed stock market reactions on debt issues for British firms during the same time span. The authors of that study provide first evidence that that the timing of debt issues is fundamental in determining the relationship between shifts in the capital structure and subsequent risk-adjusted returns. Specifically, they show significant negative abnormal stock returns for debt issue announcements during recessionary periods while the

https://doi.org/10.1108/JRF-06-2020-0129 
Berninger, M., Fiesenig, B. and Schiereck, D. (2021), "The performance of corporate bond issuers in times of financial crisis: empirical evidence from Latin America", Journal of Risk Finance, Vol. 22 No. 1, pp. 78-92.

short term reactions for issues during normal economic conditions remain insignificant. They explain this finding with a rise in market risk and loss aversion rise during recessionary periods which might vanish the potential signaling effect of growth of debt issue announcements.

Our findings indicate a significant negative difference between stock returns on recessionary and non-recessionary periods. This finding deviates from results of Koutmos et al. (2018) for the British market which brings us to the conclusion that not only the overall economic conditions matter to explain stock market reactions on bond issues but also the maturity of corporate debt markets.

This paper contributes to the existing literature as it sheds light upon how a region might influence shareholders' sentiment towards the issue of debt during periods of bad economic condition.

The remainder of this paper is structured as follows. The second section describes the nature of the sampled data and presents the used methodology. The third section details the findings and presents different interpretations to those. Finally, the fourth section summarizes and concludes this paper.

\section{SAMPLE CONSTRUCTION AND METHODOLOGY}

\subsection{Sample selection procedure}

To construct a reprehensive sample of Latin American companies for which the impact of debt issues within different market phases can be analyzed, the constituents of the S\&P 40 Latin America index will be used as the starting point. This index consists of 40 firms from five different countries (Brazil, Mexico, Chile, Peru and Colombia). From these 40 firms, 13 could not be included in the final sample because they either entered the stock market after the beginning of the study period or they did not issue any debt during this period at all.

Since we are especially interested in studying debt issues within different market phases, all debt issues announced in the period from January 1, 2003 through December 31, 2010 were included. This time span includes both periods of economic prosperity between 2003 and 2007, and times of economic recession following the events of mid-2007 that led to a global financial crisis. Furthermore, this time span was chosen with a view to Koutmos's et al. (2018) study, in order to facilitate a comparison between the (mature) British and the (emerging) Latin American market. Figure 1 illustrates the total returns of the S\&P 40 Latin America index during this time span.

https://doi.org/10.1108/JRF-06-2020-0129 
Berninger, M., Fiesenig, B. and Schiereck, D. (2021), "The performance of corporate bond issuers in times of financial crisis: empirical evidence from Latin America", Journal of Risk Finance, Vol. 22 No. 1, pp. 78-92.

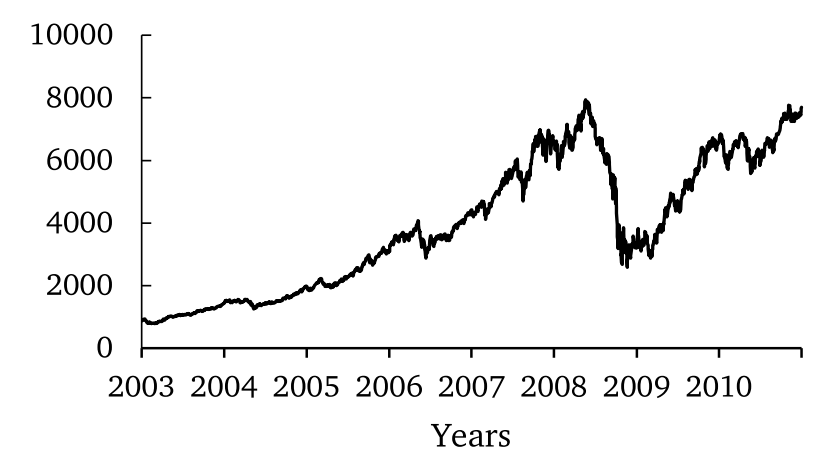

Figure 1: Time-series plot of the S\&P 40 Latin America total returns.

It can be seen that the Latin American companies were heavily affected by the financial crisis in the years 2008 and 2009 but show also an impressive growth in the remaining years which makes these market phases ideal for our intended analyses.

Table 1: Full sample of debt issues $(N=160)$.

\begin{tabular}{lccc}
\hline & Issues & Cumulative Issues & Cumulative Percentage (\%) \\
\hline Panel A: Issues by year & & & \\
2003 & 6 & 6 & 4 \\
2004 & 6 & 12 & 8 \\
2005 & 6 & 18 & 11 \\
2006 & 17 & 35 & 22 \\
2007 & 15 & 50 & 31 \\
2008 & 30 & 80 & 50 \\
2009 & 40 & 120 & 75 \\
2010 & 40 & 160 & 100 \\
Panel B: Issues by country & & & 38 \\
Brazil & 60 & 60 & 68 \\
Mexico & 49 & 109 & 88 \\
Chile & 31 & 140 & 99 \\
Colombia & 19 & 159 & 100 \\
Peru & 1 & 160 & \\
\hline
\end{tabular}

This table shows the number of debt issuance announcements for each fiscal year and its cumulative percentage in panel A. Panel B divides the debt issuance in their respective issuing countries.

In total, 160 debt issues from the companies in the sample can be identified within this time span in the database Thomson Reuters. To take into account the high leverage of financial companies, which could influence the results of the subsequent event study (Fama and French, 1992), two different samples will be analyzed; a "full" sample as well as a sample under exclusion of financial firms. The second sample without financial firms consists of 100 debt issues between 2003 and 2010. Tables 1 and 2 presents the number of issuances for both samples on a yearly and country level basis. 
Berninger, M., Fiesenig, B. and Schiereck, D. (2021), "The performance of corporate bond issuers in times of financial crisis: empirical evidence from Latin America", Journal of Risk Finance, Vol. 22 No. 1, pp. 78-92.

Table 2: Sample of debt issues excluding financial firms $(N=100)$.

\begin{tabular}{lccc}
\hline & Issues & Cumulative Issues & Cumulative Percentage $(\%)$ \\
\hline Panel A: Issues by year & & & 4 \\
2003 & 4 & 4 & 6 \\
2004 & 2 & 6 & 11 \\
2005 & 5 & 11 & 26 \\
2006 & 15 & 26 & 39 \\
2007 & 13 & 39 & 57 \\
2008 & 18 & 57 & 81 \\
2009 & 24 & 81 & 100 \\
2010 & 19 & 100 & 43 \\
Panel B: Issues by country & & & 83 \\
Brazil & 43 & 43 & 99 \\
Mexico & 40 & 83 & 100 \\
Chile & 16 & 99 & \\
Peru & 1 & 100 & \\
\hline
\end{tabular}

This table shows the number of debt issuance announcements for each fiscal year and its cumulative percentage in panel A. Panel B divides the debt issuance in their respective issuing countries.

\subsection{Event study methodology}

To derive the abnormal stock market returns around the debt issues, we follow the event study approach of MacKinlay (1997). This stands in contrast to the referred study of Koutmos et al. (2018) who use an EGARCH based model ${ }^{1}$ instead of the standard Market Model. We follow the main strand of literature and apply a Market Model combined with an ordinary least squares (OLS) estimator due to its robustness in different market environments. The abnormal returns (AR) are therefore calculated as the difference of the actual return of each security and the expected return as predicted by the market model. For firm $i$ and event day $t$, the ARs can be represented as

$$
A R_{i t}=R_{i t}-E\left(R_{i t} \mid X_{t}\right)
$$

where $A R_{i t}$ is the abnormal return, $R_{i t}$ is the actual return and $E\left(R_{i t} \mid X_{t}\right)$ is the expected return of the same firm at the same event day under the condition $X_{t}$ that no event relevant for the stock's valuation occurred. To derive the expected returns, the market model is applied. This model states a linear relation between the individual stock's return and the return of a market portfolio. In our

\footnotetext{
${ }^{1}$ The exponential generalized autoregressive conditional heteroskedastic (EGARCH) model was first introduced was by Nelson (1991) and is a special form of the generalized autoregressive conditional heteroskedasticity (GARCH) model.
} 
Berninger, M., Fiesenig, B. and Schiereck, D. (2021), "The performance of corporate bond issuers in times of financial crisis: empirical evidence from Latin America", Journal of Risk Finance, Vol. 22 No. 1, pp. 78-92.

study, the S\&P 40 Latin America represents the market portfolio. Under these assumptions, the expected returns are calculated as followed

$$
E\left(R_{i t} \mid X_{t}\right)=\alpha_{i}+\beta_{i} R_{m t}+\epsilon_{i t}
$$

where $R_{m t}$ is the market return, approximated by our representative portfolio and $\epsilon_{i t}$ is a zero mean disturbance term with a variance of $\sigma^{2} \epsilon_{i}$. The market model parameters $\alpha_{i}, \beta_{i}$ are determined by an OLS regression.

When defining $t=0$ as the event date, the time span between $T_{0}$ and $T_{1}$ can be described as the estimation window in which the market models' parameters will be estimated. The time span between $T_{1}$ and $T_{2}$ is the event window, wherein the ARs will be calculated. After $T_{2}$, the post-event window begins. Figure 2 illustrates this timeline:

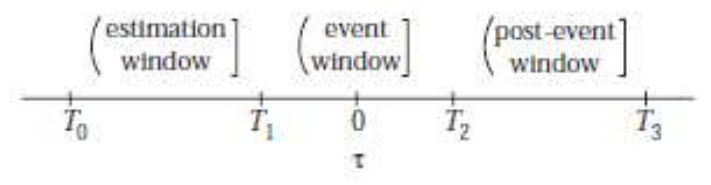

Figure 2: Timeline of an event study (MacKinley, 1997).

In this paper, $T_{0}$ corresponds to the day 120 days prior to the event date, while $T_{1}$ and $T_{2}$ capture a symmetric two day event window around the individual debt issue. ${ }^{2}$ Summing up, the estimation window will therefore be 119 days long, while the event window can extend up to three days. The estimation window starting 120 days before the event date was chosen with regard to MacKinley (1997).

In order to draw an overall conclusion, the estimated ARs have to be aggregated. Therefore, all abnormal returns from each security following a debt issue are summed up to create a cumulated abnormal return (CAR) for each event. The estimation of CARs can be expressed as followed

$$
\widehat{C A R}_{i\left(T_{1}+1 ; T_{2}\right)}=\sum_{t=T_{1}+1}^{T_{2}} \widehat{A R}_{i t}
$$

\footnotetext{
${ }^{2}$ Koutmos et al. (2018) use a slightly shorter 90 day estimation window. As a further robustness check, we repeated our analysis with this different estimation window and find almost identical results. For reasons of brevity, these results are not presented explicitly in our paper but are available from the authors upon request.
} 
Berninger, M., Fiesenig, B. and Schiereck, D. (2021), "The performance of corporate bond issuers in times of financial crisis: empirical evidence from Latin America", Journal of Risk Finance, Vol. 22 No. 1, pp. 78-92.

Finally, the cumulative average abnormal return (CAAR) for all events in the individual sample is determined based on the following expression

$$
C A A R_{(\text {Event window })}=\frac{1}{N} \sum_{i=1}^{N} \widehat{C A R}_{i(\text { Event window })}
$$

where $N$ represents the total number of events in the sample. The significance of the results is determined by four different significance tests: The parametric cross-sectional t-test and the time series t-test as well as the non-parametric standardized residual test following Patell (1976) and the sign test (Cowan, 1992).

\subsection{Regression analysis}

Since several more factors besides periods of recessions can potentially affect the capital market reactions to debt issues, we take this into account by conducting numerous regression analyses in a latter step. The included control variables will be presented and motivated in the following section.

To investigate the general role of economic cycles, three different dummy variables are introduced. The first variable is the main RECESSION variable, which equals 0 for all debt issues prior to August 9, 2007 and 1 for events following this date. This variable was defined following Koutmos et al. (2018) to ensure comparability with their results. The second dummy variable RECESSION LA is employed as a specific recession proxy for Latin America. The variable equals 0 for all debt issues prior to September 1, 2008 and equals 1 for the following issues. This variable is introduced based on Ocampo's (2009) research on the beginning of the economic recession in Latin America. Since Latin America has this far been treated as a homogeneous group of countries, the third dummy variable SENTIMENT is applied to distinguish the beginning of the economic recession between the individual Latin American countries. To do so, the index of consumer's sentiment for each specific Latin American country ${ }^{3}$ was analyzed. To define the beginning of bad sentiment of consumers, the time span between 2007 and 2010 was analyzed quarterly for four countries, since

\footnotetext{
${ }^{3}$ Brazil: BR Consumer Confidence Index - Sao Paulo VOLN / Colombia: CB Fedesarrollo Consumer Confidence Index (ICC) NADJ / Mexico: MX Consumer Confidence Index - Mexico Sadj / Chile: CL Consumer Expectations NADJ
} 
Berninger, M., Fiesenig, B. and Schiereck, D. (2021), "The performance of corporate bond issuers in times of financial crisis: empirical evidence from Latin America", Journal of Risk Finance, Vol. 22 No. 1, pp. 78-92.

the only debt issue of a Peruvian company was outside this period. The beginning of the bad sentiment period is defined by the first significant contraction of consumer's sentiment, followed by yet two consecutive quarters of significant contraction. Figure 3 illustrates the development of the consumer sentiment indices for the analyzed timespan. It can be seen that, while there is in general a similar shape, the individual beginning as well as magnitude of the recession differs between the countries. The vertical dashed line in each diagram illustrates the beginning of the recessionary period in the given country which was used for the dummy variable. As described above, this point is defined as the first of three consecutive quarters, in which the countries' consumer sentiment faces a contraction.

BRAZIL

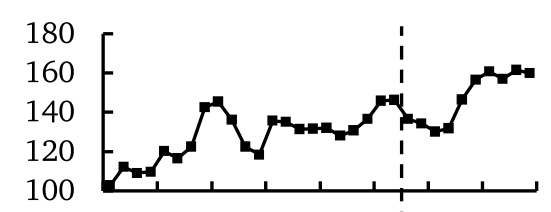

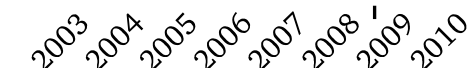
$a^{2} a^{2} a^{2} a^{2} a^{2} a^{2} a^{2} a^{2}$

CHILE

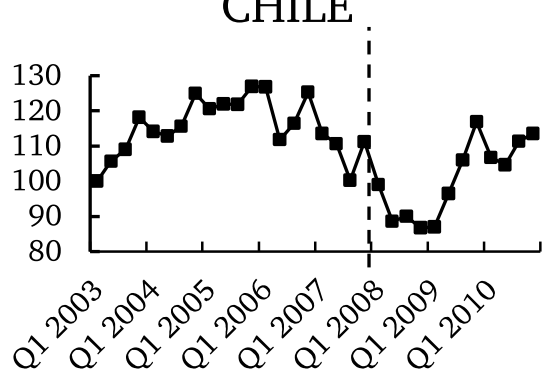

COLOMBIA

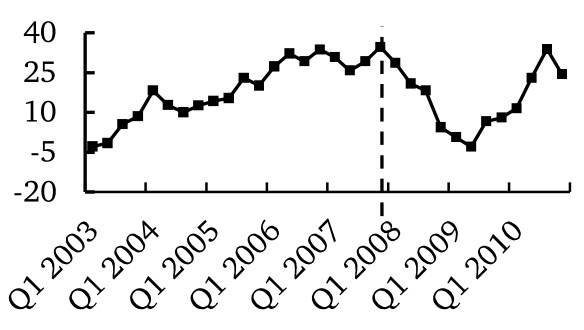

MEXICO

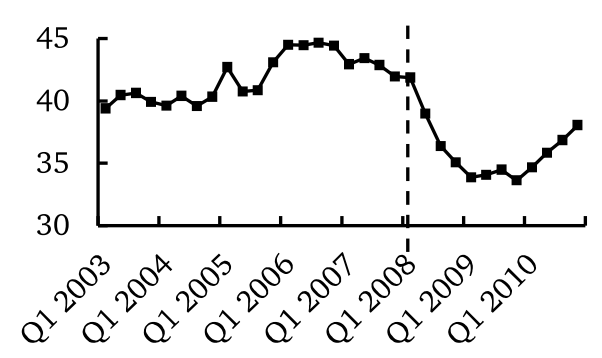

Figure 3: Consumer Sentiment in selected Latin American countries between 2003 and 2010.

With these three different proxies, we are able to granularly analyze the impact of economic recession on the stock market perception of a debt issue. Table 3 presents the number of observations for each of the three recession indicators. 
Berninger, M., Fiesenig, B. and Schiereck, D. (2021), "The performance of corporate bond issuers in times of financial crisis: empirical evidence from Latin America", Journal of Risk Finance, Vol. 22 No. 1, pp. 78-92.

Table 3: Number of issues in the periods of economic recession.

\begin{tabular}{lcc}
\hline Dummy Variable & Full sample $(\mathrm{N}=160)$ & Non-financial firms $(\mathrm{N}=100)$ \\
\hline Panel A: RECESSION & 119 & 70 \\
RECESSION $=1$ & 41 & 30 \\
RECESSION $=0$ & & \\
& 92 & 54 \\
Panel B: RECESSIONLA & 68 & 46 \\
RECESSIONLA $=1$ & & \\
RECESSIONLA $=0$ & 105 & 58 \\
Panel C: SENTIMENT & 55 & 42 \\
SENTIMENT $=1$ & SENTIMENT $=0$ &
\end{tabular}

This table shows how the samples are divided between recessionary and non-recessionary periods. Panel A, Panel B and Panel $\mathrm{C}$ divide the samples using the dummy variables RECESSION, RECESSIONLA and SENTIMENT, respectively. It is apparent that the majority of debt in the samples were issued during periods of bad economic condition. However, the debt issues in the (nonfinancial) reduced sample are distributed more equally than the full sample.

Furthermore, we employ three vectors of control variables to take firm-specific, issue-specific and country-specific characteristics into account. These are in total nine variables. A total of six out of these nine variables are firm-specific, meaning that these variables depend on the firm issuing the debt, not the issue itself. The first firm-specific variable is INVESTMENT GRADE, which proxies the issuers' credit worthiness based on its Moody's rating for long term domestic debt. In a previous study, Shyam-Sunder (1991) did not report a significant influence of credit ratings on debt issues, but in a different (nonrecession) setting. We expect in contrast that for our research setting where a generally higher risk for investors is prevailing, the issuers credit worthiness could be a more relevant factor. The next variable STATE OWNED is a dummy variable that equals 1 if the firm is majority-owned by a governmental body and 0 otherwise. This variable is relevant especially when analyzing Latin American firms, since the importance of the state sector can be considered one structural issue in the Latin American market, facilitating an economic crisis (Hakim, 1985). Another regularly used variable when investigating debt issues is the age of the company. The variable LOGAGE measures, in logarithmic terms, the years that the company has been in existence. The final contemplated year was 2010. That year, minus the year of foundation for each company (in logarithmic terms) forms the variable LOGAGE. The variable LOGMARKETCAP measures the market capitalization of the firm (in logarithmic terms) and therefore reflects the influence of the equity value of companies in the regression. The variable LOGGROSSPROFIT 
Berninger, M., Fiesenig, B. and Schiereck, D. (2021), "The performance of corporate bond issuers in times of financial crisis: empirical evidence from Latin America", Journal of Risk Finance, Vol. 22 No. 1, pp. 78-92.

includes the company's earning position and also allows insides about how the operating performance can alter investor's sentiment during a debt issue announcement.

The issue-specific variable set adds up two more indicators: The LOGPROCEEDS variable is a control for the proceeds from each debt issue (in logarithmic terms). It is applied because issues with larger proceeds might lead to a stronger shift in capital structure and therefore to different reactions of the shareholders. The MATURITY variable represents the debt maturity for each issue. Finally, we include ECONOMIC GROWTH as a country-specific variable. It indicates the GDP growth of the country where the issuing firm is located. As stated by Madura and Akhigbe (1995), an increased economic growth could positively influence abnormal returns following debt offerings. The subsequent table 4 presents descriptive statistics for all variables.

Table 4: Descriptive statistics of the variables used in the regression models.

\begin{tabular}{lrrrrrr}
\hline & $\mathrm{N}$ & Mean & Median & Std. Dev. & $\mathrm{p} 10$ & $\mathrm{p} 90$ \\
\hline RECESSION & 160 & 0.744 & 1 & 0.438 & 0 & 1 \\
RECESSION LA & 160 & 0.713 & 1 & 0.454 & 0 & 1 \\
SENTIMENT & 160 & 0.656 & 1 & 0.476 & 0 & 1 \\
& & & & & & \\
LOGPROCEEDS & 160 & 2.321 & 2.394 & 0.505 & 1.561 & 2.959 \\
MATURITY & 160 & 22.369 & 10 & 33.998 & 2 & 100 \\
ECONOMIC GROWTH & 160 & 0.151 & 0.164 & 0.068 & 0.055 & 0.217 \\
INVESTMENT GRADE & 160 & 12.262 & 12 & 3.394 & 8 & 17.5 \\
STATE OWNED & 160 & 0.125 & 0 & 0.332 & 0 & 1 \\
LOGAGE & 160 & 3.83 & 4.174 & 0.910 & 2.303 & 4.710 \\
LOGMARKETCAP & 160 & 22.99 & 22.923 & 0.980 & 21.689 & 24.156 \\
LOGGROSSPROFIT & 160 & 22.151 & 22.068 & 1.231 & 20.563 & 23.773 \\
\hline
\end{tabular}

Summing up, the OLS regressions take the following form:

$$
\operatorname{CAR}_{i, t}=\alpha+\beta \times \operatorname{BUSINESSCYCLE}_{i, t}+\delta \times \operatorname{FIRM}_{i, t}+\vartheta \times \operatorname{ISSUE}_{i, t}+\varphi \cdot \operatorname{COUNTR}_{i, t}+\varepsilon(5)
$$


Berninger, M., Fiesenig, B. and Schiereck, D. (2021), "The performance of corporate bond issuers in times of financial crisis: empirical evidence from Latin America", Journal of Risk Finance, Vol. 22 No. 1, pp. 78-92.

In this regression equation, BUSINESSCYCLE stands for one of our three different regression proxies we described above. Note that the three indicators were not included simultaneously in the same model specification. Instead, we estimate three models were each indicator is included exclusively.

As a last step of our study, it will finally be analyzed how the perceived risk by the investors and therefore the market model parameters might change between crisis periods and periods of financial growth. To perform this analysis, the median and the mean value from the estimated riskadjusted returns and systematic risk will be derived. The difference will show how the model that describes shareholder's sentiment towards debt issue announcements changes depending on the current economic situation.

\section{RESULTS}

\subsection{Event study results}

In the following section, our empirical results are presented. In a first step, we visualize the estimated CAARs (Table 5) for the full sample as well as for the sub sample without financial companies. We than analyze the difference between the CAARs following debt issues during good macroeconomic conditions in contrast to times of recessions (both for the entire sample and the sub samples without financial services, respectively) in Tables 6 and 7. The significance of the results is presented by the best fitting significance test for the given CAAR.

Table 5: Cumulative average abnormal returns.

\begin{tabular}{|c|c|c|c|c|c|}
\hline Event Window & CAAR (\%) & $\begin{array}{c}\text { t-test Times } \\
\text { Series }\end{array}$ & $\begin{array}{c}\text { t-test Cross- } \\
\text { tional }\end{array}$ & Patell z & Sign Test \\
\hline \multicolumn{6}{|c|}{ Panel A: Non-financial firms $(N=100)$} \\
\hline$[-1 ;+1]$ & -0.36 & -1.014 & -0.903 & -0.555 & 13.851 \\
\hline$[0 ;+1]$ & -0.18 & -0.604 & -0.495 & 0.150 & 0.585 \\
\hline$[-1 ; 0]$ & -0.50 & $-1,735^{*}$ & -1.323 & -0.914 & 0.785 \\
\hline \multicolumn{6}{|c|}{ Panel B: Full sample $(N=160)$} \\
\hline$[-1 ;+1]$ & -0.34 & -12.272 & -10.454 & -0.578 & $17.913^{*}$ \\
\hline$[0 ;+1]$ & -0.46 & $-20.137^{* *}$ & -14.361 & -0.818 & 16.332 \\
\hline$[-1 ; 0]$ & -0.16 & -0.710 & -0.618 & 0.382 & -0.423 \\
\hline \multicolumn{6}{|c|}{$\begin{array}{l}\text { This table presents the cumulative average abnormal returns following a debt issue. Three different event windows } \\
\text { are applied to reflect the reaction following the issue of debt. The remaining columns present four different applied } \\
\text { tests to verify the significance of the according CAAR. *,**, *** indicate statistical significance at the } 10 \%, 5 \% \text {, } \\
\text { and } 1 \% \text { level, respectively. }\end{array}$} \\
\hline
\end{tabular}


Berninger, M., Fiesenig, B. and Schiereck, D. (2021), "The performance of corporate bond issuers in times of financial crisis: empirical evidence from Latin America", Journal of Risk Finance, Vol. 22 No. 1, pp. 78-92.

It can be seen that in general there are significantly negative capital market reactions following debt issues in the Latin American market. These reactions of about $-0.5 \%$ are prevalent for both firms in the financial as well as the non-financial segment. The magnitude of the results are comparable to those reported by Koutmos et al. (2018) for the UK. Furthermore, the results are also in line with the findings of Howton et al. (1998), who analyzed straight-bond issues at the US market during a period in general almost good economic sentiment. They report average abnormal returns between $-0.24 \%$ and $-0.56 \%$ following these debt issues.

In the next step, we investigate the influence of the macroeconomic situation on the capital market reactions.

Table 6: CAAR by economic conditions for the sample without financial firms.

\begin{tabular}{|c|c|c|c|}
\hline $\begin{array}{l}\text { Event Win- } \\
\text { dow }\end{array}$ & $\begin{array}{c}\text { CAAR } \\
\text { RECESSION }(\mathrm{N}=70) \\
\end{array}$ & $\begin{array}{c}\text { CAAR } \\
\text { NON-RECESSION }(\mathrm{N}=30) \\
\end{array}$ & Difference \\
\hline \multicolumn{4}{|c|}{$\begin{array}{l}\text { Panel A: CAAR with } \\
\text { RECESSION variable }\end{array}$} \\
\hline$[-1 ;+1]$ & $\begin{array}{l}-0.54 \% \\
(-11.553)\end{array}$ & $\begin{array}{l}0.05 \% \\
\{0.105\}\end{array}$ & $\begin{array}{l}-0.59 \% \\
(-0.815)\end{array}$ \\
\hline$[0 ;+1]$ & $-0.51 \%$ & $0.62 \% * *$ & $-1.13 \% *$ \\
\hline$[-1 ; 0]$ & $\begin{array}{l}(-13.573) \\
-0.49 \% \\
(-12.92)\end{array}$ & $\begin{array}{l}\{19.636\} \\
-0.53 \% \\
\{-0.981\}\end{array}$ & $\begin{array}{l}(-1.962) \\
0.04 \% \\
(0.060)\end{array}$ \\
\hline $\begin{array}{l}\text { Event Win- } \\
\text { dow }\end{array}$ & $\begin{array}{c}\text { CAAR } \\
\text { RECESSIONLA } \\
(\mathrm{N}=54) \\
\end{array}$ & $\begin{array}{c}\text { CAAR } \\
\text { NON-RECESSIONLA } \\
(\mathrm{N}=46) \\
\end{array}$ & Difference \\
\hline \multicolumn{4}{|c|}{$\begin{array}{l}\text { Panel B: CAAR with } \\
\text { RECESSIONLA variable }\end{array}$} \\
\hline$[-1 ;+1]$ & $\begin{array}{l}-0.49 \% \%^{* *} \\
((23.357))\end{array}$ & $\begin{array}{l}-0.21 \% \\
(-0.522)\end{array}$ & $\begin{array}{l}-0.28 \% \\
(-0.368)\end{array}$ \\
\hline$[0 ;+1]$ & $\begin{array}{l}-0.66 \% \\
(-14.256)\end{array}$ & $\begin{array}{l}0.39 \% \\
(1.213)\end{array}$ & $\begin{array}{l}-1.05 \% \\
(-1.564)\end{array}$ \\
\hline$[-1 ; 0]$ & $\begin{array}{l}-0.45 \%^{*} \\
((17.912))\end{array}$ & $\begin{array}{l}-0.57 \%{ }^{*} \\
(-17.526)\end{array}$ & $\begin{array}{l}0.12 \% \\
(0.154)\end{array}$ \\
\hline $\begin{array}{l}\text { Event Win- } \\
\text { dow }\end{array}$ & $\begin{array}{c}\text { CAAR } \\
\text { BAD SENTIMENT } \\
(\mathrm{N}=58) \\
\end{array}$ & $\begin{array}{c}\text { CAAR } \\
\text { GOOD SENTIMENT } \\
(\mathrm{N}=42) \\
\end{array}$ & Difference \\
\hline \multicolumn{4}{|c|}{ Panel C: CAAR with } \\
\hline$[-1 ;+1]$ & $\begin{array}{l}-0.47 \%{ }^{* *} \\
((22.692))\end{array}$ & $\begin{array}{l}-0.20 \% \\
(-0.506)\end{array}$ & $\begin{array}{l}-0.27 \% \\
(-0.359)\end{array}$ \\
\hline$[0 ;+1]$ & $\begin{array}{l}-0.64 \% \\
(-14.507)\end{array}$ & $\begin{array}{c}0.46 \% * \\
((19.400))\end{array}$ & $\begin{array}{c}-1.10 \% * \\
(-1.705)\end{array}$ \\
\hline$[-1 ; 0]$ & $\begin{array}{l}-0.54 \%{ }^{*} \\
((17.438))\end{array}$ & $\begin{array}{l}-0.46 \% \\
(-13.915)\end{array}$ & $\begin{array}{l}-0,08 \% \\
(-0.113)\end{array}$ \\
\hline
\end{tabular}


Berninger, M., Fiesenig, B. and Schiereck, D. (2021), "The performance of corporate bond issuers in times of financial crisis: empirical evidence from Latin America", Journal of Risk Finance, Vol. 22 No. 1, pp. 78-92.

Each panel in this table presents the resulting cumulative abnormal returns using three different dummy variables to divide the sample without financial firms into two sub-samples: one of bad and one of good economic condition. The last column presents the difference between the resulting CAARs. Time-series t-tests are presented by (.), crosssectional t-tests by $\{$.$\} , sign tests by (()$.$) and Patell \mathrm{z}$ values by [.]. *,**,*** indicate statistical significance at the $10 \%, 5 \%$, and $1 \%$ level, respectively.

Table 7: CAAR by economic conditions for the full sample.

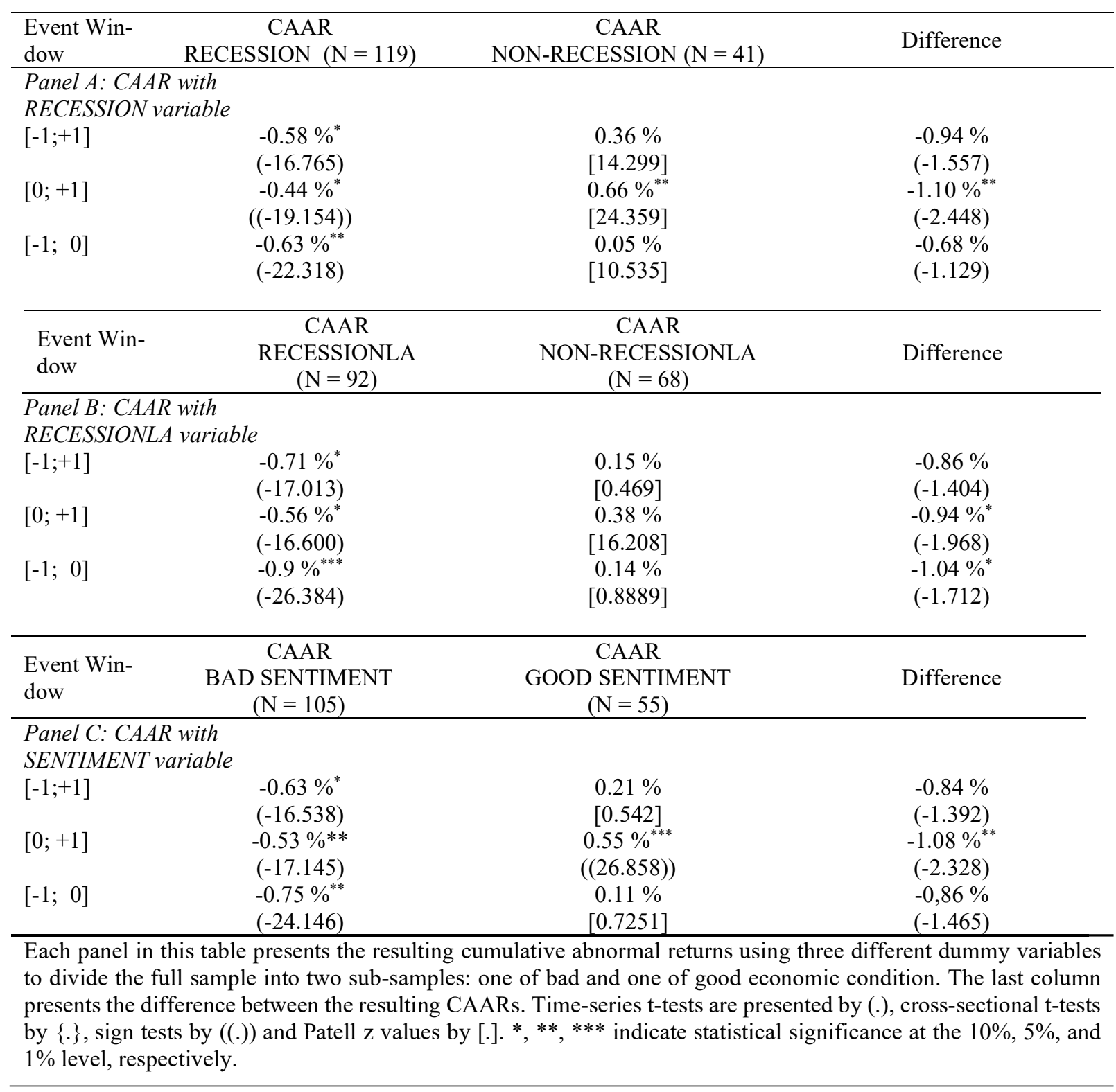

By considering the macroeconomic conditions around the issue, significant differences between recession and non-recession periods can be observed. While in recession periods the capital market 
Berninger, M., Fiesenig, B. and Schiereck, D. (2021), "The performance of corporate bond issuers in times of financial crisis: empirical evidence from Latin America", Journal of Risk Finance, Vol. 22 No. 1, pp. 78-92.

reaction is negative for both financial and non-financial firms, in non-recession periods this finding reverses to significant positive market reactions around the announcement date at the Latin American market. These findings are robust for all of our three recession indicators. The results stand in partial contrast to Koutmos et al. (2018) who also report differences between sub-samples of good and bad economic conditions but do not observe this turnaround in the sign of the CAARs. For periods of good economic sentiment, their results lose any statistical significance. Furthermore, the findings of Howton et al. (1998) lead in the same direction. While they analyze a period with in general a very good economic sentiment, they nevertheless observe on average negative abnormal stock-market returns following debt issues on the mature US market.

Therefore, at this point of our analysis, two important things can be concluded: First of all, we provide additional evidence to the previous literature that issuing a corporate bonds in times of economic recessions seems to be interpreted adversely by investors. Furthermore, our results might be seen as a first evidence that, additionally to the overall economic conditions, the maturity of the corporate debt market matters to explain stock market reactions on bond issues.

\subsection{Regression results}

To shed further light on the factors explaining these distinct stock market reactions on debt issues at the Latin American market, we subsequently conduct several regression analyses for our three different recession indicators. The results of these regressions are presented in Table 8 . 
Berninger, M., Fiesenig, B. and Schiereck, D. (2021), "The performance of corporate bond issuers in times of financial crisis: empirical evidence from Latin America", Journal of Risk Finance, Vol. 22 No. 1, pp. 78-92.

Table 8: Results of the regression analysis.

\begin{tabular}{|c|c|c|c|}
\hline & Model 1 & Model 2 & Model 3 \\
\hline & RECESSION & RECESSIONLA & SENTIMENT \\
\hline RECESSION & $\begin{array}{l}-0.015^{*} \\
(-1.922)\end{array}$ & - & - \\
\hline RECESSION LA & - & $\begin{array}{l}-0.013^{*} \\
(-1.674)\end{array}$ & - \\
\hline SENTIMENT & - & - & $\begin{array}{l}-0.017^{* *} \\
(-2.351)\end{array}$ \\
\hline LOGPROCEEDS & $\begin{array}{c}0.013^{*} \\
(1.917)\end{array}$ & $\begin{array}{c}0.013^{*} \\
(1.871)\end{array}$ & $\begin{array}{c}0.012^{*} \\
(1.828)\end{array}$ \\
\hline MATURITY & $\begin{array}{l}0.0002^{*} \\
(1.875)\end{array}$ & $\begin{array}{l}0.0002^{*} \\
(1.833)\end{array}$ & $\begin{array}{c}0.0002^{* *} \\
(2.146)\end{array}$ \\
\hline ECONOMIC GROWTH & $\begin{array}{c}0.078 \\
(1.212)\end{array}$ & $\begin{array}{c}0.083 \\
(1.292)\end{array}$ & $\begin{array}{c}0.109^{*} \\
(1.667)\end{array}$ \\
\hline INVESTMENT GRADE & $\begin{array}{l}0.003^{* * *} \\
(2.664)\end{array}$ & $\begin{array}{l}0.003^{* *} \\
(2.589)\end{array}$ & $\begin{array}{l}0.003^{* * *} \\
(2.807)\end{array}$ \\
\hline STATE OWNED & $\begin{array}{l}-0.027^{*} \\
(-1.974)\end{array}$ & $\begin{array}{l}-0.026^{*} \\
(-1.894)\end{array}$ & $\begin{array}{l}-0.033^{* *} \\
(-2.156)\end{array}$ \\
\hline LOGAGE & $\begin{array}{c}0.003 \\
(0.624)\end{array}$ & $\begin{array}{c}0.003 \\
(0.736)\end{array}$ & $\begin{array}{c}0.002 \\
(0.573)\end{array}$ \\
\hline LOGMARKETCAP & $\begin{array}{c}0.003 \\
(0.321)\end{array}$ & $\begin{array}{c}0.003 \\
(0.420)\end{array}$ & $\begin{array}{c}0.001 \\
(0.148)\end{array}$ \\
\hline LOGGROSSPROFIT & $\begin{array}{c}0.004 \\
(0.623)\end{array}$ & $\begin{array}{c}0.003 \\
(0.498)\end{array}$ & $\begin{array}{c}0.005 \\
(0.775)\end{array}$ \\
\hline Intercept & $\begin{array}{l}-0.227^{* *} \\
(-2.493)\end{array}$ & $\begin{array}{l}-0.231^{* *} \\
(-2.522)\end{array}$ & $\begin{array}{l}-0.222^{* *} \\
(-2.445)\end{array}$ \\
\hline F statistic & $2.147^{* *}$ & $2.038^{* *}$ & $2.372^{* *}$ \\
\hline $\mathrm{R}^{2}$ & $11.41 \%$ & $10.89 \%$ & $12.46 \%$ \\
\hline Adj. $\mathrm{R}^{2}$ & $6.10 \%$ & $5.55 \%$ & $7.21 \%$ \\
\hline $\mathrm{n}$ & 160 & 160 & 160 \\
\hline
\end{tabular}

This table presents estimates for the coefficients from regression (11) using the full sample. Each column presents the coefficients from the models with different main explanatory variables. Two-tail t-test results are in parentheses (.). ${ }^{*},{ }^{* *},{ }^{* * *}$ indicate statistical significance at the $10 \%, 5 \%$, and $1 \%$ level, respectively.

All three main explanatory variables show significant coefficients, suggesting that the macroeconomic conditions play an important role for the stock market perception of debt issues at in Latin America. In general, the model applying the variable SENTIMENT appears to be the best fitting model with an adjusted $\mathrm{R}^{2}$ of $7.21 \%$. Nevertheless, all three models hold significant $\mathrm{F}$ statistics 
Berninger, M., Fiesenig, B. and Schiereck, D. (2021), "The performance of corporate bond issuers in times of financial crisis: empirical evidence from Latin America", Journal of Risk Finance, Vol. 22 No. 1, pp. 78-92.

and satisfactory values for the adjusted $\mathrm{R}^{2}$. Therefore, from a methodical standpoint, it can be concluded that cross-country studies examining the influence of economic cycles and especially the impacts of financial crises should be vigilant by modelling these effects, since the perceived beginning of a crisis might differ even within "homogeneous" regions like Latin America.

The negative values for the main explanatory variables are as hypnotized, indicating that recessionary periods have indeed a negative influence on the shareholders' reaction to debt issues. The control variables LOGPROCEEDS and MATURITY show significant coefficients with signs as suggested by fundamental economic theories of risk distribution. Interestingly, the variable INVESTMENT GRADE is also positive and significant, which stands in contrast to the findings of Shyam-Sunder (1991) who does not report a significant influence. Finally, the variable STATE OWNED shows significant negative coefficients in all three models, indicating that debt issues by these companies lead on average to lower stock market reactions. Due to the strong governmental influence on these companies, debt issues might comprise a different signal in terms of the future perspectives of the company to the outside investors.

\subsection{Differences in systematic risks}

To assess the impact of recessionary periods on the capital market's risk-perception around corporate debt-issuances, we finally perform an analysis of the parameters of the market model used to calculate the abnormal returns. We therefore interpret the alpha-parameters as a representation of risk-adjusted returns and the beta-parameters as a representation of the firm's systematic risk.

The previous findings indicate that the returns following debt issues are very dependable on the current economic situation in Latin America. Furthermore, the prior results in table 7 gave evidence that short term negative reactions to debt issues are common during recessionary periods, while during good economic conditions, positive returns are likely to occur following a debt issue.

In this context the model parameters can shed light on the nature of the stock market environment during periods of good versus bad economic conditions. Table 9 presents the mean and median values of the alpha and beta coefficients estimated in the market model, which used to calculate the abnormal returns. 
Berninger, M., Fiesenig, B. and Schiereck, D. (2021), "The performance of corporate bond issuers in times of financial crisis: empirical evidence from Latin America", Journal of Risk Finance, Vol. 22 No. 1, pp. 78-92.

Table 9: Model parameters for full sample and economic conditions sub-samples.

\begin{tabular}{|c|c|c|c|c|c|c|c|c|}
\hline \multicolumn{3}{|c|}{$\begin{array}{r}\text { Panel A: RECESSION } \\
\text { Full Sa }\end{array}$} & \multicolumn{2}{|c|}{ Recession } & \multicolumn{2}{|c|}{ Non-Recession } & \multicolumn{2}{|c|}{$\begin{array}{c}\text { Difference between } \\
\text { sub-samples }\end{array}$} \\
\hline Alpha & $\begin{array}{c}\text { Mean } \\
0.00011\end{array}$ & $\begin{array}{l}\text { Median } \\
0.00009\end{array}$ & $\begin{array}{c}\text { Mean } \\
0.00014\end{array}$ & $\begin{array}{l}\text { Median } \\
0.00009\end{array}$ & $\begin{array}{c}\text { Mean } \\
0.00002\end{array}$ & $\begin{array}{l}\text { Median } \\
-0.00016\end{array}$ & $\begin{array}{c}\text { Mean } \\
0.00011^{* * *}\end{array}$ & $\begin{array}{l}\text { Median } \\
0.00025^{*}\end{array}$ \\
\hline Beta & 0.80451 & 0.75577 & 0.74467 & 0.70089 & 0.97819 & 0.97267 & $-0.23353^{* * *}$ & $-0.27178^{* * *}$ \\
\hline \multicolumn{3}{|c|}{$\begin{array}{r}\text { Panel B: RECESSION LA } \\
\text { Full Sample }\end{array}$} & Reces & nLA & Non-Re & sionLA & \multicolumn{2}{|c|}{$\begin{array}{c}\text { Difference between } \\
\text { sub-samples }\end{array}$} \\
\hline Alpha & $\begin{array}{c}\text { Mean } \\
0.00011\end{array}$ & $\begin{array}{l}\text { Median } \\
0.00009\end{array}$ & $\begin{array}{c}\text { Mean } \\
0.00037\end{array}$ & $\begin{array}{l}\text { Median } \\
0.00030\end{array}$ & $\begin{array}{c}\text { Mean } \\
-0.00024\end{array}$ & $\begin{array}{l}\text { Median } \\
-0.00016\end{array}$ & $\begin{array}{c}\text { Mean } \\
0.00061\end{array}$ & $\begin{array}{l}\text { Median } \\
0.00046\end{array}$ \\
\hline Beta & 0.80451 & 0.75577 & 0.79147 & 0.75577 & 0.82214 & 0.77854 & -0.03067 & -0.02277 \\
\hline
\end{tabular}

Panel C: SENTIMENT

\begin{tabular}{cccccc} 
& \multicolumn{2}{c}{ Full Sample } & & \multicolumn{2}{c}{ Bad Sentiment } \\
\cline { 2 - 3 } \cline { 5 - 6 } Alpha & 0.00011 & 0.00009 & & 0.00033 & 0.00013 \\
Beta & 0.80451 & 0.75577 & & 0.75896 & 0.75100
\end{tabular}

Good Sentiment

$\begin{array}{cc}\text { Mean } & \text { Median } \\ -0.00031 & -0.00031 \\ 0.89146 & 0.86374\end{array}$

Difference between sub-samples

\begin{tabular}{cc}
\hline Mean & Median \\
0.00064 & 0.00043 \\
-0.13250 & -0.11274
\end{tabular}

This table presents the risk-adjusted returns (alpha) and systematic risk parameters (beta) for the full sample (including financial firms), for the sub-samples regarding recessionary and non-recessionary periods, and, in the last column, the difference between those sub-samples with corresponding statistical tests. *,**,*** indicate statistical significance at the $10 \%, 5 \%$, and $1 \%$ level of a two-tail t-test, respectively a Wilcoxon Rank-Sum test.

Surprisingly, the difference between the model parameters for Latin American companies are contrary to the British companies as documented by Koutmos et al. (2018). While the risk-adjusted returns in Latin America tend to be higher during recessionary periods and the systematic risk lowers, the risk-adjusted returns and the systematic risk show the opposite reaction in the UK in the presence of a recession. A reaction that can also be expected globally during the pandemic caused by COVID-19, where the VIX (Chicago Board Options Exchange's Volatility Index) index for volatility of the S\&P 500 (as another measure for perceived risk) has reached its highest mark since its creation (Ercolani and Natoli, 2020). The difference could result from the selection of companies issuing debt during the mentioned periods. As Slimane et al. (2017) analyze in detail, a generally perceived rise in the betas in times of crises does not affect all companies and industry segments equally. Instead, they report a rise in the beta in some cases and a decrease in others.

For our sample, it could be the case that only financially strong, reliable firms issue debt during periods of bad economic sentiment in Latin America. However, when analyzing Koutmos' et al. 
Berninger, M., Fiesenig, B. and Schiereck, D. (2021), "The performance of corporate bond issuers in times of financial crisis: empirical evidence from Latin America", Journal of Risk Finance, Vol. 22 No. 1, pp. 78-92.

(2018) model parameters, one can assume that British companies are not averse of issuing debt during recessionary periods, even if it means to have smaller returns compared to the risk taken. A reason for this finding could be the comparably underdevelopment of the Latin American debt market, which could limit the ability for some firms to raise capital in periods of challenging economic conditions. This underdevelopment becomes even clearer when comparing the size of the Latin American debt market to more developed markets such as the British or the US-American one. E.g. in the year 2005, the combined size of the corporate debt issues for the seven biggest debt issuing countries in Latin America had roughly a volume of $3 \%$ of the corporate debt issues in the US (Jeanneau and Tovar, 2008). Without the culture of corporate bond markets, it is possible that Latin American investors will not be as affected to the issue of new corporate debt as British or American investors, and rather focus on the overall quality of the company active during this period.

\section{CONCLUSION}

Our study aims to examine whether the macroeconomic sentiment has influence in stock returns following debt issue announcements in Latin America. We provide first evidence that previously described changes in the returns on specific stocks depending on the economic sentiment (Baker and Wurgler, 2006) are under certain conditions also present in the market for corporate debt. More precisely, our findings indicate a significant negative difference between stock returns on recessionary and non-recessionary periods in the Latin American market. This finding partially differs from results of Koutmos et al. (2018) for the British market. At this mature market only in times of economic recessions there are significant stock reactions on debt issues present. Summing this up, our study also provides additional evidence that corporate bond issuing in recessions are interpreted adversely by investors. In conjunction with the results from our differently specified proxies for economic sentiment, we further conclude that not only the overall economic conditions matter to explain stock market reactions on bond issues but also the maturity of corporate debt markets.

Therefore the transfer of previous empirical findings on mature markets might cause misleading results on emerging markets. Furthermore and from a practitioner's standpoint, rising debt capital in this kind of markets should strongly be accompanied by comprehensive managerial signals which indicates the future perspectives of the company. 
Berninger, M., Fiesenig, B. and Schiereck, D. (2021), "The performance of corporate bond issuers in times of financial crisis: empirical evidence from Latin America", Journal of Risk Finance, Vol. 22 No. 1, pp. 78-92.

\section{REFERENCES}

Alfaro, L., Asis, G., Chari, A. and Panizza, U. (2017), "Lessons Unlearned? Corporate Debt in Emerging Markets", CEPR Discussion Papers 12038, C.E.P.R. Discussion Papers, available at: https://cepr.org/active/publications/discussion_papers/dp.php?dpno=12038.

Baker, M. and Wurgler, J. (2006), "Investor Sentiment and the Cross-Section of Stock Returns", The Journal of Finance, Vol. 61 No. 4, pp. 1645-1680.

Cowan, A. R. (1992). "Nonparametric event study tests", Review of Quantitative Finance and accounting, Vol. 2 No. 4, 343-358.

Dann, L. and Mikkelson, W. (1984), "Convertible debt issuance, capital structure change and financing-related information", Journal of Financial Economics, Vol. 13 No. 2, pp. 157-186.

Davydov, D. (2016), "Debt structure and corporate performance in emerging markets", Research in International Business and Finance, Vol. 38, pp. 299-311.

Davydov, D., Nikkinen, J. and Vähämaa, S. (2014), "Does the decision to issue public debt affect firm valuation? Russian evidence", Emerging Markets Review, Vol. 20 No. 1, pp. 136-151.

Davydov, D. and Vähämaa, S. (2013), "Debt source choices and stock market performance of Russian firms during the financial crisis", Emerging Markets Review, Vol. 15, pp. 148-159.

Dichev, I. and Piotrosky, J. (1999), "The Performance of Long-run Stock Returns Following Issues of Public and Private Debt", Journal of Business Finance \& Accounting, Vol. 26 Nos 9-10, pp. 1103-1132.

Eckbo, B.E. (1986), "Valuation effects of corporate debt offerings", Journal of Financial Economics, Vol. 15 Nos. 1-2, pp. 119-151.

Ercolani, V. and Natoli, F. (2020), "Market volatility and the length of the Covid-19 recession", Econbrowser, available at: https://econbrowser.com/archives/2020/05/guest-contributionmarket-volatility-and-the-length-of-the-covid-19-recession (accessed 2 May 2020).

Fama, E.F. and French, K.R. (1992), "The Cross-Section of Expected Stock Returns", The Journal of Finance, Vol. 47 No. 2, pp. 427-465.

Franko, P. (2019), "The Global Financial Crisis and Latin America", Latin American Research Review, Vol. 54 No. 1, pp. 286-293.

Godlewski, C., Fungáčová, Z. and Weill, L. (2011), "Stock Market Reaction to Debt Financing Arrangements in Russia", Comparative Economic Studies, Vol. 53 No. 11, pp. 679-693.

Hakim, Jonathan (1985), "Latin America's Financial Crisis: Causes and Cures”, in E. (Ed.): Latin America and the World Recession, Cambridge University Press, Cambridge, pp. 17-37.

Howton, S., Howton, S. and Perfect, S. (1998), "The market reaction to straight debt issue: the effects of free cash flow", The Journal of Financial Research, Vol. 21 No. 2, pp. 219-228.

Jeanneau, S. and Tovar, C.E. (2008), "Latin America's local currency bond market: an overview". BIS Papers 36, February 2008. BIS and FRB, Atlanta, available at: http://www.bis.org/publ/bppdf/bispap36d.pdf. 
Berninger, M., Fiesenig, B. and Schiereck, D. (2021), "The performance of corporate bond issuers in times of financial crisis: empirical evidence from Latin America", Journal of Risk Finance, Vol. 22 No. 1, pp. 78-92.

Jewell, J. and Livingston, M. (1997), “The long-run performance of firms issuing bonds", Journal of Fixed Income, Vol. 7 No. 2, pp. 61-66.

Jones, Marc (2020), “Coronavirus bringing record \$1 trillion of new global corporate debt in 2020: report", Reuters Business News, available at: https://www.reuters.com/article/us-healthcoronavirus-corpdebt/coronavirus-bringing-record-1-trillion-of-new-global-corporate-debtin-2020-report-idUSKCN24D0UP (accessed 13 July 2020).

Koutmos, D., Bozos, K., Dionysiou, D. and Lambertides, N. (2018), “The timing of new corporate debt issues and the risk-return tradeoff", Review of Quantitative Finance and Accounting, Vol. 50 No. 4, pp. 943-978.

Mackinlay, A.C. (1997), "Event Studies in Economics and Finance", Journal of Economic Literature, Vol. 35 No. 1, pp. 13-39.

Madura, J. and Akhigbe, A. (1995), "Influence of economic factors on the valuation effects of debt offerings". Applied Economics, Vol. 27 No. 10, pp. 907-915.

Modigliani, F. and Miller, M.H. (1958), "The cost of capital, corporate finance and the theory of investment", The American Economic Review, Vol. 48 No. 3, pp. 261-297.

Nelson, B.D. (1991), "Conditional heteroskedasticity in asset returns: a new approach”, Econometrica, Vol. 59, pp. 347-370, doi: 10.2307/2938260.

Ocampo, J.A. (2009), "Latin America and the Global Financial Crisis", Cambridge Journal of Economics, Vol. 33 No. 4, pp. 703-724.

Patell, J. M. (1976), "Corporate forecasts of earnings per share and stock price behavior: Empirical test", Journal of Accounting Research, Vol.14 No. 2, pp. 246-276.

Shyam-Sunder, L. (1991), “The Stock Price Effect of Risky versus Safe Debt”, Journal of Financial and Quantitative Analysis, Vol. 26 No. 4, pp. 549-558.

Slimane, I. B., Bellalah, M., and Rjiba, H. (2017), "Time-varying beta during the 2008 financial crisis-evidence from North America and Western Europe", The Journal of Risk Finance, Vol. 18 No. 4, pp. 398-431.

Spiess, D.K.; Affleck-Graves, J. (1999), “The long-run performance of stock returns following debt offerings", Journal of Financial Economics, Vol. 54 No. 1, pp. 45-73.

UN News (2020), "COVID-19 to cause biggest economic contraction ever in Latin America \& Caribbean”, available at: https://news.un.org/en/story/2020/04/1062292 (accessed April 21 2020).

van der Vegt, G. S.; Essens, P.; Wahlström, M. and George, G. (2015), "Managing Risk and Resilience", Academy of Management Journal, Vol. 58 No. 4, pp. 971-980. 